\title{
CEPAEA HORTENSIS (O. F. MÜLLER, 1774) (MOLLUSCA: GASTROPODA) IN CROATIA?
}

\author{
VESNA ŠTAMOL ${ }^{1}$ \& RAJKo SLAPNIK ${ }^{2}$ \\ ${ }^{1}$ Croatian Natural History Museum, 10000 Zagreb, Croatia \\ ${ }^{2}$ Drnovškova pot 2, 1240 Kamnik, Slovenia
}

\begin{abstract}
Štamol, V. \& Slapnik, R.: Cepaea hortensis (O. F. Müller, 1774) (Mollusca: Gastropoda) in Croatia? Nat. Croat., Vol. 24, No. 2., 331-336, Zagreb, 2015.

Based on characteristics provided by the genital organs, the presence of the species Cepaea hortensis (O. F. Müller, 1774), reported from Croatia from a single site in the literature, is refuted. According to our current knowledge this species should be deleted from the terrestrial snail fauna of Croatia.
\end{abstract}

Key words: land snails, Cepaea hortensis, Croatia

Štamol, V. \& Slapnik, R.: Cepaea hortensis (O. F. Müller, 1774) (Mollusca: Gastropoda) u Hrvatskoj? Nat. Croat., Vol. 24, No. 2., 331-336, Zagreb, 2015.

$\mathrm{Na}$ osnovu determinacije po spolnim organima negirano je postojanje vrste Cepaea hortensis na jednom jedinom literaturnom nalazištu u Hrvatskoj, te je zaključeno da prema sadašnjim spoznajama vrstu treba brisati iz faune kopnenih puževa Hrvatske.

Ključne riječi: kopneni puževi, Cepaea hortensis, Hrvatska

According to literature data, there are three species of the genus Cepaea in Croatia: $C$. hortensis (O. F. Müller, 1774), C. nemoralis (Linnaeus, 1758) and C. vindobonensis (C. Pfeiffer, 1828). The genus Cepaea is understood here after BANK, 2013, while NeIBER \& HausDORF, 2015 introduce a new genus Caucasotachea for Cepaea vindobonensis. C. nemoralis and C. vindobonensis were mentioned in the earliest malacology papers concerning the Croatian area and have been reported to the present day (for example KüsTER, 1842; Anonymus, 1846; Frauenfeld, 1856; Bielz, 1865; Brusina, 1866, 1867, 1870, 1872; ErJaVec, 1874; Cubich, 1875; Clessin, 1879; Stossich, 1879, 1880, 1883; Böttger, 1880, 1880A; Hirc, 1881, 1886, 1905, 1910, 1918; Sturany, 1895; Soós, 1904; Kormos, 1907; Wagner, 1932; Bole, 1958; Štamol, 1989, 1995, 2010; BANK, 2007, 2010, 2013; HÉRA \& UHERKovich, 2008; Uнerкovich et al., 2008). In contrast, C. hortensis was recorded as a certain species for Croatia in 1867 (BrusinA, 1867), while just 13 years earlier, it was listed as a questionable record for Dalmatia (Strobel, 1854). The first detailed locality, Podsused, which is found within the present day city limits of Zagreb, was given by the Croat S. BRusina (1870). However, S. Clessin (1879), a German malacologist who conducted numerous studies in Croatia, was uncertain of the accuracy of this determination. O. BöTTGER (1880), another German malacologist, also claimed that he did not know whether this species indeed lives in Croatia. Once again, CLESSIN (1887) expressed his doubt regarding the presence of this species in Croatia. Further authors either cited Brusina's record, or collected the species themselves at the only published record in Croatia (HorvátH, 1887; Soós, 1904; 
Tab. 1. Cepaea nemoralis from Podsused, Zagreb and island of Rab. SH: shell height; SW: shell width.

\begin{tabular}{|l|l|c|c|c|c|c|c|}
\hline $\begin{array}{l}\text { specimen } \\
\text { label }\end{array}$ & Locality & $\begin{array}{c}\text { SH } \\
(\mathrm{mm})\end{array}$ & $\begin{array}{c}\text { SW } \\
(\mathrm{mm})\end{array}$ & shell lip & $\begin{array}{c}\text { distal mucus } \\
\text { gland (no. of } \\
\text { branches) }\end{array}$ & $\begin{array}{c}\text { proximal mucus } \\
\text { gland (no. of } \\
\text { branches) }\end{array}$ & dart \\
\hline $6768-2$ & Podsused, Zagreb & 17 & 23 & purple-brown & 3 & 3 & \\
\hline $6768-3$ & Podsused, Zagreb & 17 & 23 & white & 3 & 2 & \\
\hline $6768-4$ & Podsused, Zagreb & 17 & 22 & purple-brown & 3 & 3 & \\
\hline $6770-1$ & Podsused, Zagreb & 14 & 20 & white & 4 & 3 & $\begin{array}{c}\text { simple } \\
\text { blades }\end{array}$ \\
\hline $6770-2$ & Podsused, Zagreb & 17 & 22 & white & 3 & 3 & $\begin{array}{c}\text { simple } \\
\text { blades }\end{array}$ \\
\hline $6770-3$ & Podsused, Zagreb & 15 & 22 & white & 2 & 2 & 4 \\
\hline $6770-4$ & $\begin{array}{c}\text { Podsused, Zagreb } \\
17\end{array}$ & 22 & white & 4 & 3 & $\begin{array}{l}\text { simple } \\
\text { blades }\end{array}$ \\
\hline$x$ & $\begin{array}{r}\text { Kampor, Island of } \\
\text { Rab }\end{array}$ & 16 & 21 & white & 3 & $\begin{array}{l}\text { simple } \\
\text { blades }\end{array}$ \\
\hline
\end{tabular}

Hirc, 1905; Csiki, 1906; Kormos, 1907; Štamol, 1989). Because of these later publications, suspicions as to the accuracy of the determination were dissipated. Therefore, it comes as no surprise that the Fauna Europaea database and other comprehensive malacofauna works cite Croatia as within the distribution range of the species C. hortensis (EHrmanN, 1933; BANK, 2007, 2010, 2013; ŠTAMOL, 2010; LAJTNER et al., 2013).

The problem in differentiating C. hortensis and C. nemoralis is that both species display a high amount of shell variation in size, colour and banding (KLEMM, 1973; CAMERON \& Redfern, 1976; Kerney \& Cameron, 1979; Kerney et al., 1983; Horsák et al., 2013). As a rule, the shell of $C$. hortensis should be smaller than that of $C$. nemoralis, have a parallel upper and a columellar lip edge, a lighter lip and greater distance of the lowest spiral band from the umbilicus, while the shell of $C$. nemoralis is characterised by a darker lip, shorter distance of the lowest spiral band from the umbilicus, and the non-parallel positioning of the upper and columellar mouth edge (KLemm, 1973; Kerney \& CAMERON, 1979; Kerney et al., 1983; Fechter \& FALKNER, 1990). The latter criteria can be the result of subjective assessment, which is not usually reliable. Both species have morphs that lack a lower spiral band, and therefore the distance of the lower spiral band from the umbilicus cannot always serve for their differentiation. The colour of the lip remains a relatively easy differentiating characteristic. However, there are individuals of " $\mathrm{C}$. nemoralis in which white-lipped shells occur, and of C. hortensis in which dark-lipped forms occur" (CAMERoN, 2003), which hinders determination with certainty. CAMERON (2003) believes that individuals with a non-standard lip colour "are usually in a minority among the population, and it is usually obvious that they are the same size as those with the "right" lip colour." The general opinion is that the only certain differentiation is possible by the anatomy of the genital organs and their formation (AUBERTIN, 1927), in particular by the "structure of the mucus glands, and of the dart itself"CAMERON (2003), which in the case of " $C$. hortensis has bifurcated blades ... while [that] of $C$. nemoralis is simple. C. hortensis usually has 4 or more branches of each mucus gland, C. nemoralis 3 
or less" (Kerney \& Cameron, 1979). The same differences in the genital organs were mentioned by Kerney et al. (1983) and Welter-Schultes (2012).

In order to be certain which species is present at Podsused, V. Štamol and E. Kletečki collected specimens there of dark-lipped and light-lipped Cepaea for dissection. In the spring of 2015, Mr Žarko Krstinić sent the first author a specimen of a light-lipped Cepaea from the island of Rab which, in terms of lip colouration, could be considered $C$. hortensis. The anatomy of the genital organs was examined in the specimen from the island of Rab and from seven specimens of Cepaea from the only literature locality for $C$. hortensis for Croatia: Podsused in Zagreb. Of these seven specimens, two had a pronounced dark lip, while five had a white lip. The number of branches of each mucus gland ranged from 2 to 4 (Tab. 1). In all individuals displaying a love dart, it had the shape characteristics of $C$. nemoralis, including two specimens with four branches of the mucus gland. On the basis of this analysis, it was concluded that according to the current knowledge, $C$. hortensis is not present at the only literature locality, or on the island of Rab, and it should be deleted from the Croatian fauna, and therefore from the Red List of Terrestrial Snails of Croatia (LAJTNER et al., 2013).

C. hortensis is a central European species (Ehrmann, 1933; Jaeckel et al., 1958; KLemm, 1973), or can be considered a western/central European species (Kerney \& CAMERON, 1979; Kerney et al., 1983). According to the literature data, regarding nearby countries, it has been recorded in Hungary (BANK, 2007, 2013), primarily its western part (KLEMM, 1973; Kerney et al., 1983), Austria (BANK, 2007, 2013), primarily its northern part (KLEmm, 1973), Bosnia (Ehrmann, 1937; JAeckel et al., 1958; BAnK, 2010), Montenegro (BANK, 2010), Serbia and/or Kosovo (BANK, 2010). Slovenia is not included in the distribution range according to Fauna Europaea (BANK, 2007, 2013) and BANK (2010), though in some papers, C. hortensis is reported as present in its area (Bole, 1969; Polenec, 1973; Bole 1974, 1977; Bole \& Slapnik 1997; Vaupotič \& Velkovrh, 1997; Culiberg et al., 1998). JAECKEL et al. (1958) lists "Istria, croatische Littorale", which means Istria and/or the Croatian Littoral (in Croatian: Hrvatsko primorje). As previously stated (ŠTAMOL, 2010), this term is no proof of the existence of the species in Croatia, (i) because this does not confirm its presence in the Croatian Littoral, (ii) because the Istria Peninsula is encompassed by two countries (Croatia and Slovenia), and often the region of Trieste (Italy) has been included as part of this peninsula. However, it does suggest that this species is present somewhere in those regions, either the Croatian part of the northern Adriatic or the nearby areas of Slovenia and/or Italy. It should certainly be noted that C. hortensis is not recorded as present in Italy (AlzonA, 1971; KLEMM, 1973; BANK, 2010, 2013). Unfortunately, there are no data to indicate whether the determinations for Slovenia, Bosnia, Montenegro, Serbia and/or Kosovo, and for Istria and/or Croatian Littoral were performed on the basis of the anatomy of the genital organs. All facts considered, the data on the general distribution range of $C$. hortensis do not conclusively state that this species is not present in Croatia, though the data tend to support this conclusion. Also, the current conclusion of the absence of C. hortensis in Croatia also raises suspicions as to its presence in Bosnia, Montenegro, Serbia and/or Kosovo, and perhaps in all or in parts of Slovenia.

C. hortensis is spreading vigorously in Hungary and probably will occur sooner or later in Slavonia, which is a Croatian region that borders Hungary (FEHÉr, pers. comm.).

In 2011 (Silvertown et al., 2011; FeHÉr, pers. comm.) there was a citizen science based project Evolution MegaLab. Cepaea species were used as the model organism, data were collected by a wide range of volunteers and were used in evolutionary and ecological 
studies. The recent paper reveals that the distinction between $C$. hortensis and C. nemoralis is not such an easy task as previously believed and therefore those studies which are based on citizen science-collected data should be treated with some reservation.

\section{ACKNOWLEDGEMENTS}

We would like to thank Mr Žarko Krstinić for the specimen of Cepaea from the island of Rab, and Eduard Kletečki MSc for assistance in collecting specimens in Zagreb. The authors would like to thank anonymous reviewers for valuable comments and suggestions in the manuscript.

Received July 10, 2015

\section{REFERENCES}

Alzona, C., 1971: Malacofauna Italica. Catalogo e bibliografia dei molluschi viventi, terrestri e d'acqua dolce. Atti Soc. Ital. Sci. Nat. Mus. Civ. Stor. Nat. Milano 111, 1-433.

Anonymous, 1846: Conchiliologia. La Dalmazia 2 (41), 434-436.

Aubertin, D., 1927: On the Anatomy of the Land Snails (Helicidae) Cepaea hortensis Müller and Cepaea nemoralis L. Proc. Zool. Soc. London 97 (3), 553-582.

BANK, R. A., (ed.) 2007: Mollusca, Gastropoda. Fauna Europaea version, 1.3, http://www.faunaeur.org/.

BANK, R. A., 2010: Fauna europaea project. Checklist of species-group taxa of the continental Mollusca (excl. Bivalvia) living in Albania and former Yugoslavia. Manuscript, updated by Ruud A. Bank, 2512-2010.

BANk, R. A., (ed.) 2013: Mollusca, Gastropoda. Fauna Europaea version, 2.6.2, http://www.faunaeur.org/

Bielz, E. A., 1865: Systematisches Verzeichniss der Land- und Süsswasser-Mollusken des österreichischen Kaiserstaates. Verh. Mitt. siebenbürg. Ver. Naturw. Hermannstadt 16, 223-234.

BoLE, J., 1958: Zoogeografski pregled malakofavne otoka Krka. Biol. vestn. 6, 118-123.

BoLE, J., 1969: Ključi za določevanje živali. Mehkužci. Mollusca. 115 pp. Inštitut za biologijo Univerze v Ljubljani, Društvo biologov Slovenije, Ljubljana.

BoLE, J., 1974: Malakološke značilnosti loškega ozemlja [Die malakologischen Eigenheiten des Gebietes von Škofja Loka]. Loški razgledi 21, 156-162.

BoLE, J., 1977: Živalski svet Lubnika. Mehkužci. In: Ramovš, A. (ed.): Lubnik. Vodniki po loškem ozemlju. Muzejsko društvo, p. 70-74.

Bole, J. \& SlapNiK, R., 1997: Molluscs (Gastropoda: Prosobranchia, Pulmonata; Bivalvia) of the Kočevje and Ribnica region (Slovenia). Razprave IV razr. SAZU 38, 137-163.

BötTger, O., 1880: Aufzählung der von Herrn Edmund Reitter in Wien im Frühjahr 1880 in dem westlichen Montenegro, in Süd-Dalmatien und in Süd-Croatien gesammelten Mollusken. Ber. Offenbacher Ver. Naturkunde 19/21, 100-115.

Boettger [Böttger], O., 1880a: Aufzählung der von Herrn Edmund Reitter in Wien im Jahre 1879 in Süd-Croatien und Dalmatien gesammelten Mollusken. Jahrb. Deutsch. Malakozool. Ges. 7, 224-235.

Brusina, S., 1866: Contribuzione pella Fauna dei molluschi dalmati. Verh. k. k. zool. bot. Ges. Wien 16, Beilage, 1-134.

BRUsina, S., 1867: Prinesci malakologiji hrvatskoj. Rad JAZU 1, 78-105.

Brusina, S., 1870: Contribution à la malacologie de la Croatie. 40 pp. Albrecht \& Fiedler, Zagreb.

BRUsina, S., 1872: Naravoslovne crtice sa sjevero-istočne obale jadranskoga mora, sabrao god. 1868 i 1871. Dio prvi. Rad JAZU 19, 105-177.

Cameron, R. A. D., 2003: Land snails in the British Isles. iv + 82 pp. Field Studies Council, Occasional Publication 79, Shropshire.

Cameron, R. A. D. \& Redfern, M., 1976: British Land Snails. Synopses of the British Fauna (New Series) 6.64 pp. The Linnean Society of London, Academic Press London, New York San Francisco.

Clessin, S., 1879: Zur Molluskenfauna Croatiens. Nachrichtsb. Deutsch. Malakozool. Ges. 11, 116-125. 
Clessin, S., 1887: Die Molluskenfauna Oesterreich-Ungarns und der Schweiz. 869 pp. Bauer \& Raspe, E. Küster, Nürnberg.

CsIKI, E, 1906: Fauna regni hungariae. Animalium hungariae hucusque cognitorum enumeratio systematica. II Mollusca. 44 pp. Regia societas scientiarum naturalium hungarica, Budapest.

Cubich, G., 1875: Documenti sull isola di Veglia raccolti per cura del Dr. Giambattista Cubich. p. 1-129. Appolonio \& Caprin, Tieste.

Culiberg, M., Babij, V., Seliškar, A., Trrin, D., Vreš, B., Prus, M., Zupančić, M., Žagar, V., Accetto, M., Čarni, A., Drovenik, B., Čelik, T., Tome, S., Slapnik, R., Mršić, N., 1998: In: M. Zupančič (ed.), Biotopska in biocenotska valorizacija reke Mure in zaledja z oceno ranljivosti (zaključno poročilo). 215 pp. Biološki inštitut Jovana Hadžija ZRC SAZU, Ljubljana.

Ehrmann, P., 1933: Mollusca. 264 pp., 147 Abb., 13 Taf. In: Brohmer, P., Ehrmann, P., Ulmer, G.: Die Tierwelt Mitteleuropas. Band II. Quelle \& Meyer, Leipzig.

ERJAVEC, F., 1874: Slavonija u malakologičnom pogledu. Rad JAZU 31, 69-81.

Fechter, R. \& Falkner, G., 1990: Weichtiere. 287 pp. Mosaik Verlag, München.

Frauenfeld, G., 1856: Beitrag zur Fauna Dalmatien's. Verh. zool. bot. Ver. Wien 6, 431-448.

Héra, Z. \& Uherkovich, Á., 2008: Malacological data (Mollusca) from the Croatian Drava region (N Croatia). p. 121-130. In: Purger, J. J. (ed.): Biodiversity studies along the Drava river. University of Pécs, Hungary.

Hirc, D., 1881: Die Mollusken-Fauna des liburnischen Karstes. Verh. k. k. zool. bot. Ges. Wien 30, 519-530.

Hirc, D., 1886: Malacologische Mittheilungen. Verh. k. k. zool. bot. Ges. Wien 36, 377-390.

Hrrc, D., 1905: Prirodni zemljopis Hrvatske. Knjiga prva: Lice naše domovine. 721 pp. A. Scholz, Zagreb.

Hirc, D., 1910: Malakološki prilozi. Glasn. Hrvats. prirodosl. društva 22 (2/2), 40-63.

Hirc, D., 1918: Prilozi malakofauni hrvatskog Zagorja. Glasn. Hrvats. prirodosl društva 30, $143-145$.

Horsák M., JuřičKová L. \& PickA, J., 2013: Měkkýši České a Slovenské republiky. Molluscs of the Czech and Slovak Republics. 270 pp., Kabourek, s.r.o., Zlin.

Horváth, G., 1887: Izlet u Podsused u zagrebačkoj okolici mjeseca novembra. Glasn. Hrvats. naravoslov. družtva 2 (4/6), 267-274.

Jaeckel, S. G., Klemm, W. \& Meise, W., 1958: Die Land- und Süsswasser-Mollusken der nördlichen Balkanhalbinsel. Abh. Ber. Mus. Tierk. Dresden 23 (2),141-205.

Kerney, M. P. \& Cameron, R. A. D., 1979: A field guide to the land snails of Britain and North-west Europe. 288 pp. Collins, London.

Kerney, M. P. \& Cameron, R. A. D. \& Jungbluth, J. H., 1983: Die Landschnecken Nord- und Mitteleuropas. 384 pp. Paul Parey, Hamburg und Berlin.

KLemm, W., 1973: Die Verbreitung der rezenten Land-Gehäuse-Schnecken in Österreich. Denkschr. Österr. Akad. Wiss. 117, Math. nat. K1., (=Supplement 1 des Catalogus Faunae Austriae), 1-503.

Kormos, T., 1907: Beiträge zur Molluskenfauna von Kroatien. Nachrichtsb. Deutsch. Malakozool. Ges. 39 (4), 181-197.

Küster, H. C., 1842: Naturhistorische Reiseberichte aus Dalmatien und Montenegro. Isis von Oken 1842 (10), 744-752.

LAJTNER, J., ŠTAMOL, V. \& SLAPNiK, R., 2013: Crveni popis kopnenih i slatkovodnih puževa Hrvatske. Emys, Zagreb (http://www.dzzp.hr/vrste/crveni-popis-biljaka-i-zivotinja-rh/crveni-popis-biljaka-i-zivotinjarepublike-hrvatske-146.html)

Neiber, M. T. \& Hausdorf, B., 2015. Molecular phylogeny reveals the polyphyly of the snail genus Cepaea (Gastropoda: Helicidae). Molecular Phylogenetics and Evolution 93, 143-149.

Polenec, A., 1973: Nekaj posebnosti in zanimivosti iz živalstva Loškega ozemlja. Loški razgledi 19, 356-374.

Silvertown, J., Cook, L. M., Cameron, R. A. D., Dodd, M. E., Mcconway, K. J., Jones, J. S., Worthington, J. P., Skelton, P., Anton, C., Bosdorf, O., Baur, B., Schilthuizen, M., Fontaine, B., Sattmann, H., Bertorelle, G., Correia, M., Oliveira, C., Pokryszko, B., Ozgo, M., Stalazs, A., Gill, E., Rammul, U., Solymos, P., Fehér, Z. \& XAVIER, J., 2011: Citizen science reveals unexpected continental-scale evolutionary change in a model organism. PLoS ONE 6(4) e18927, doi:10.1371/journal.pone.0018927.

Soós, L., 1904: Magyarország Helicidái. Állattani Közlemények 3 (3), 134-184.

Sтоssich, A., 1879: Il Velebit. Boll. Soc. Adriat. Sci. Nat. Trieste 4, 5-25.

Stossich, A., 1880: Il Carso Liburnico. Boll. Soc. Adriat. Sci. Nat. Trieste 5, 333-351.

Sтоssich, A., 1883: I Molluschi del Velebit. Boll. Soc. Adriat. Sci. Nat. Trieste 8, 132-140. 
Strobel, P., 1854: Molluschi terrestri raccolti da Cristoforo Bellotti nel 1853 in Dalmazia, con note ed aggiunte di P. Strobel. Giornale di Malacologia 2, 49-62, 114-123, 136-141, 145-151.

Sturany, R., 1895: Sammelreise nach den Plitvicer Seen in Croatien. Annal. k. k. Naturhist. Hofmuseums Wien, 10 (2) (Notizen), 79-82.

ŠтамоL, V., 1989: Contribution to the Study of Land Snails (Gastropoda) of Medvednica Mountain (NW Croatia, Yugoslavia). Scopolia 17, 1-17.

ŠтAмоL, V., 2010: A list of the land snails (Mollusca: Gastropoda) of Croatia, with recommendations for their Croatian names. Nat. Croat. 19 (1), 1-76.

Štamol, V. \& Velkovrh, F., 1995: Contribution to the knowledge of land snail fauna of the islands of Cres and Lošinj (Croatia) (Gastropoda: Prosobranchia, Basommatophora, Stylommatophora). Malak. Abh. Mus. Tierkd. Dresden 17 (20), 219-237.

Uherkovich, Á., Purger, D. \& Csiky, J., 2008: First find of Pomatias rivularis (Eichwald, 1829) (Mollusca: Pomatiidae) in Croatia. Nat. Croat. 17 (3), 183-192.

Vaupotič, M. \& Velkovrh, F., 1997: Prispevek k poznavanju favne mehkužcev (Mollusca) v severovzhodni Sloveniji [Contribution to the knowledge of molluscan fauna (Mollusca) in Northeastern Slovenia]. Acta biol. slov. 41 (1), 37-45.

Wagner, H., 1932: Weitere Mitteilungen über die Molluskenfauna von Abbazia und Umgebung. Atti Real. Ist. Veneto sci. lett. art. 91 (2), 729-736.

Welter-Schultes, F. W, 2012: European non-marine molluscs, a guide for species identification. 679 pp. Planet Poster Editions, Göttingen. 